\title{
A scientist's walk through Hanoi Old Quarter Houses
}

\author{
Bui Dieu Quynh \\ National Centre for Sustainable Development of General Education Quality \\ Vietnam National Institute of Educational Sciences \\ Ministry of Education and Training \\ 101 Tran Hung Dao street, Hoan Kiem District, Hanoi 100000, Vietnam \\ Email: buidieuquynh2019@gmail.com
}

Hanoi, September 14, 2019

\begin{abstract}
Hanoi - the capital city of Vietnam and the land of thousand years of civilization - invokes among both locals and tourists the image of the 'Sword Lake' with its ancient 'Turtle Tower' and the charming Old Quarter with its preserved old houses lying along small commercial alleys. The houses in the Old Quarter were constructed over a century ago which feature tube houses with inclined tile roofs and a blend of French architecture create the infusions of history and memory. Researchers of various fields have attempted to capture and explain the essence of these townhouses in their works, either in the collectibles of many authors, the quintessential drawings of talented painters, or in publications on the history of the Old Quarter $[1,2,3]$. Among these, the recent work by Vuong et al. (2019) adds a unique view of the architectural features of Hanoi's ancient townhouses as these features are viewed as dependent and independent variables. The study titled 'Cultural evolution in Vietnam's early 20th century: A Bayesian network analysis of Hanoi Franco-Chinese house designs' aims to find traces of cultural evolution in the early $20^{\text {th }}$ century in Vietnam and highlight the most notable elements that affect the Vietnamese people's perception of cultural evolutions [4].
\end{abstract}

The most striking feature of this study is the methodology employed to analyze and interpret the data. This study is the first among research conducted on the architecture of Hanoi ancient townhouses to employ the Bayesian network analysis method. The method has served well for the researchers to systematically investigate the relationship of elements that are most commonly 'captured' in paintings, photos, observations, and document analysis. A comprehensive review of the history of the development and factors shaping the architectural features of Hanoi ancient townhouses has also been provided in the study to enhance the analysis of the qualitative data. This study is also the first of its kind in Vietnamese socio-cultural research to code 248 photos of ancient townhouses as dependent and independent variables in a spreadsheet file.

The second most significant contribution of the study lies in the findings from the Bayesian network analysis $[5,6,7]$. The study reveals a hybrid in cultural and religious representations from the decoration of the façade of Hanoi ancient townhouses. Chinese and French cultural influences have been found to come into terms with strong religious influence from Confucianism, Buddhism, and Taoism to shape what is currently visible on the façade. Buddhism, in particular, has had a strong impact on the exterior decorations of the houses, which is an interesting discovery that the study has made. The evidence grounded on the scientific analysis of the study confirms the value and historical evidence of Hanoi ancient townhouses in this modern-day architecture. 
This account is not concerned with possible limitations of the study as the study itself is a creative attempt in the field of social science research in Vietnam, a country that still lags far behind the world in terms of scientific publications and still embarks on methodological approaches that have long been cultivated in the world $[8,9]$. Other than the study of Vietnamese folklore by the same research team [10], there are no previous studies which employ a similar methodology for comparison to be made against this study. The study can be argued to have motivated Vietnamese social science researchers who are looking for new approaches to articulating statements of problems, selecting research materials, interpreting research findings, and aiming for high-quality research [11]. This is particularly enriching at a time when the study of culture and history are dominantly reliant on qualitative research and judgments have mostly been grounded on long-standing knowledge gathered [12].

These commentaries made above are from the view of the writers as educational researchers. The study has opened up a different perspective on a completely new approach to social research. The study itself has also highlighted the critical importance of appreciating and preserving socio-cultural values of the capital city of Vietnam, particularly when the ongoing modernization trend can potentially lead to the disappearance and conversion of monuments for those historical-cultural developments $[13,14]$.

\section{References:}

[1] Kien, T. (2008). "Tube House" and "Neo Tube House" in Hanoi: A Comparative Study on Identity and Typology. Journal of Asian Architecture and Building Engineering, 7(2), 255-262.

[2] Kien, T. (2008). Conservation pressing task and new documentation of old tube houses in Hanoi Old Quarter through the case of No. 47 Hang Bac Street house. 日本建築学会計画系論文集, 73(624), 457-463.

[3] Vuong, Q. H., Ho, M. T., Vuong, T. T., Tran, K., \& Ho, M. (2018). "Paintings can be forged, but not feeling": Vietnamese art-market, fraud, and value. Arts, 7(4), 62, DOI: 10.3390/arts7040062.

[4] Vuong Q.-H., Bui Q.-K., La V.-P., Vuong T.-T., Ho M.-T., Nguyen H.-K.T., Nguyen H.-N., Nghiem K.-C.P. \& Ho M.-T. (2019). Cultural evolution in Vietnam's early 20th century: a Bayesian networks analysis of Hanoi Franco-Chinese house designs. Social Sciences \& Humanities Open, DOI: 10.1016/j.ssaho.2019.100001

[5] McElreath, R. (2016). Statistical rethinking: A Bayesian course with examples in R and Stan. Boca Raton, FL: CRC Press.

[6] Kruschke, J. (2015). Doing Bayesian data analysis: A tutorial with R, JAGS, and Stan [2nd ed]. London, UK: Elsevier.

[7] Scutari, M., and Denis, J. B. (2014). Bayesian networks: with examples in R. London and New York: Chapman and Hall/CRC.

[8] Manh, H. D. (2015). Scientific publications in Vietnam as seen from Scopus during 19962013. Scientometrics, 105, 83-95.

[9] Nguyen, T. V., Ho-Le, T. P. \& Le, U. V. (2017). International collaboration in scientific research in Vietnam: an analysis of patterns and impact. Scientometrics, 110, 1035-1051. 
[10] Vuong, Q. H., La, V. P., Vuong, T. T., Nguyen, V. H., Ho, M. T., Nguyen, T. H. K., ... \& Ho, M. T. (2018). Cultural additivity: Behavioural insights from the interaction of Confucianism, Buddhism, and Taoism in folktales. Palgrave Communications, 4, 143, DOI: $10.1057 / s 41599-018-0189-2$

[11] Vuong, Q. H. (2018). The (ir)rational consideration of the cost of science in transition economies. Nature Human Behaviour, 2(1), 5, DOI: 10.1038/s41562-017-0281-4

[12] Whitehouse, P., \& Francois, P. (2019, May 5). A bad time for (some) theories but a good time for history?. Cliodynamica. Retrieved from http://peterturchin.com/ cliodynamica/a-bad-time-for-some-theories-but-a-good-time-for-history/ (September 14, 2019).

[13] Thanh, N. (2019, Sept 13). Hanoi's old quarter overrun by vacation crowds for MidAutumn Festival. VnExpress. Retrieved from https://e.vnexpress.net/ news/travel/places/hanoi-s-old-quarter-overrun-by-vacation-crowds-for-mid-autumnfestival-3981616.html (September 14, 2019).

[14] Tam, T. (2016, Dec 12). Hanoi finds ways to preserve Old Quarter. Vietnam Economics News. Retrieved from http://ven.vn/hanoi-finds-ways-to-preserve-old-quarter24375.html (September 14, 2019). 